(*)
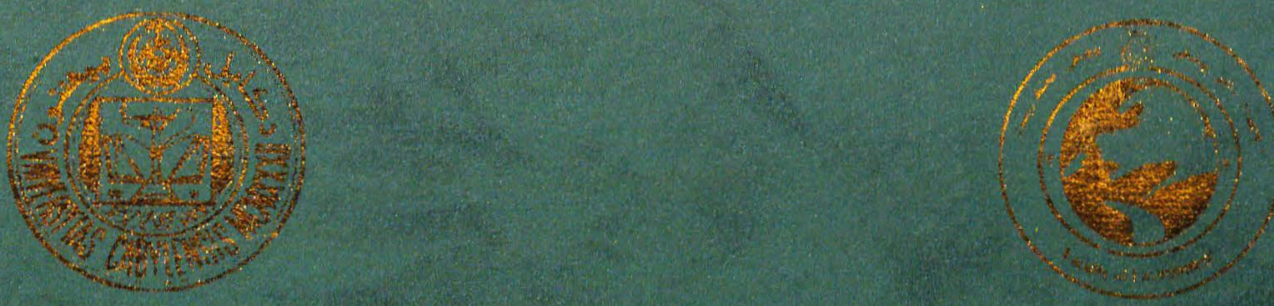

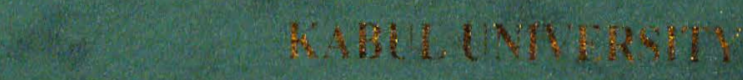

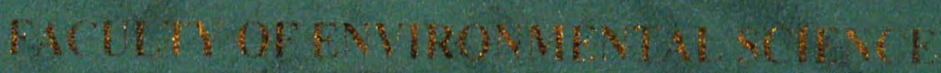

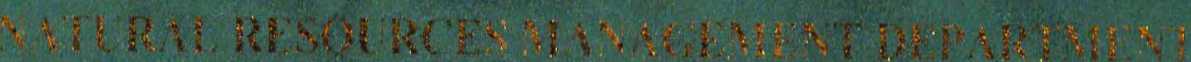

17.

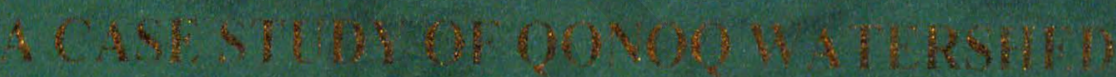

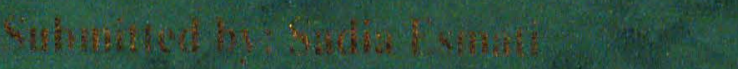

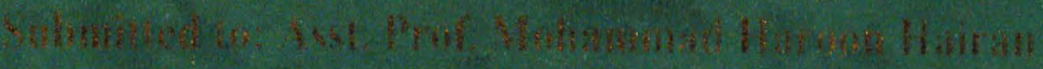

(10) 

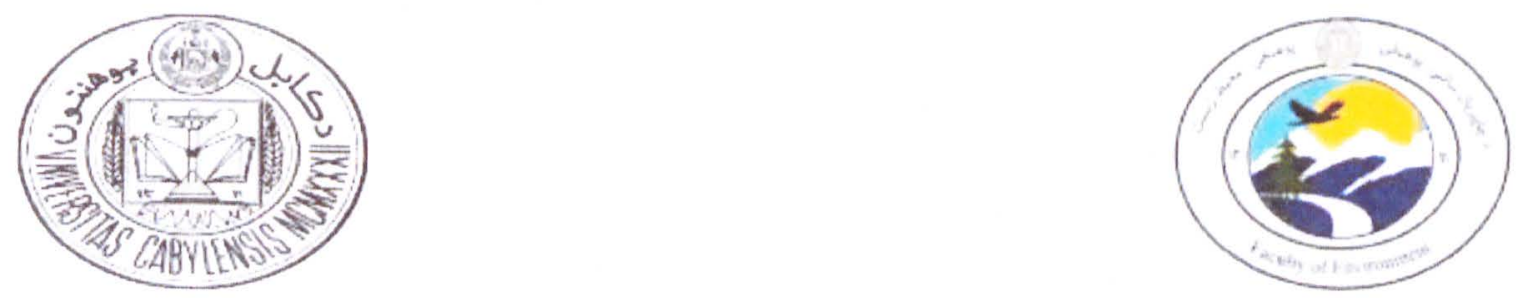

KABUL UNIVERSITY

FACULTY OF ENVIRONMENTAL SCIENCE

NATURAL RESOURCES MANAGEMENT DEPARTMENT

\section{INTEGRATED WATERSHED MANAGEMENT} A CASE STUDY OF QONOQ WATERSHED

Submitted by: Sadia Esmati

Submitted to: Asst. Prof. Mohammad Haroon Hairan

Year: 2018 
بسم الله الرهمن الربهي 


\section{ACKNOWLEDGMENT}

In performing my monograph, I had to take the help and guideline of some respected persons, who deserve my greatest gratitude. The completion of this monograph gives me much Pleasure. I would like to show to my supervisor assistant Professor Mohammad Haroon Hairan at department of NRM, Environmental Science faculty of Kabul University, for his valuable guidance and support throughout my monograph. I would also like to expand my deepest gratitude to all those who have directly and indirectly guided me in writing this monograph.

In addition, a thank to assistant Professor Samiullah Sofizad and Assistant Pro. Wafaurahman Wafa, who introduced me to the methodology of work, and whose passion for the "underlying structures" had lasting effect.

Many people, especially my classmates have made valuable comment suggestions on this proposal which gave me an inspiration to improve my monograph. I thank all the people for their help directly and indirectly to complete my monograph. 


\begin{abstract}
Despite growing concern over the management of watersheds in view of environmental and economic implications of their degradation, there is a confusion as to why watersheds should be considered conservation and development planning units. Likewise, watershed development and management projects receive low priority because of unattractive direct benefits reflected in traditional types of cost-benefit analysis. Inconsistency is found in the basic framework of programs, including activities, implemented in different watersheds of the same country. Many watershed management projects have been implemented in South and Southeast Asian Countries with ad hoc institutional arrangements, which disappear with the termination of the projects. Such confusions, inconsistencies and ad hoc arrangements are detrimental to sustainable watershed management. This monograph is an attempt to address the above issues. It starts with the rationale for a watershed approach to conservation and development, followed by a general assessment of benefits accruing from watershed management and associated beneficiaries. Major issues in watershed development are outlined and their causes are examined in watershed of Qonoq. The watershed of Qonoq lies in the most southerly district of Bamyan province. With communities found ranging between 2,900 and $3,300 \mathrm{~m}$, the region experiences prolonged winter conditions, has few cropping options, and relies on melt snow for most of its water requirements. Finally, the approach to watershed management is suggested against the backdrop of watershed management issue.
\end{abstract}




\section{TABLE OF CONTENTS}

Aknowledgment.

Abstract. ...

\section{Chapter 1}

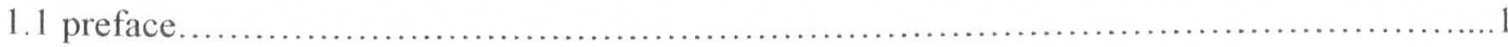

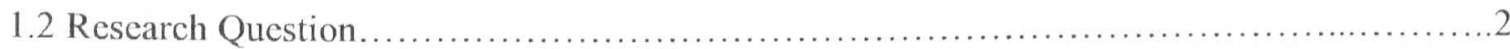

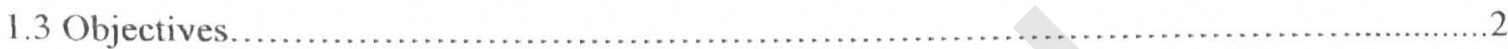

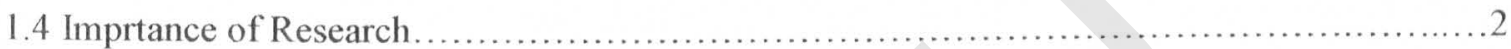

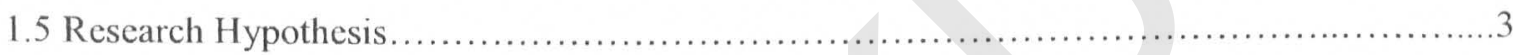

Chapter 2

Introduction

2.1 Watershed .4

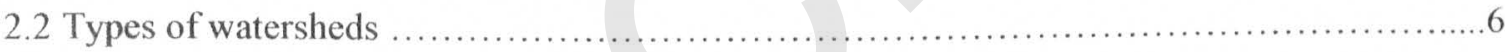

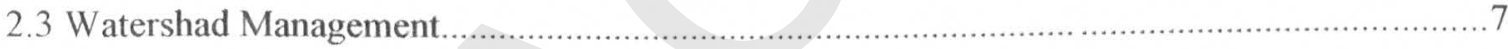

2.5 Watershed Management Approaches and Methodologies................................

2.6 The Policy and Legal Framework of Watershed Management ........................... 8

2.4 The Evolution of National Policies in Watershed Management …................................... 8

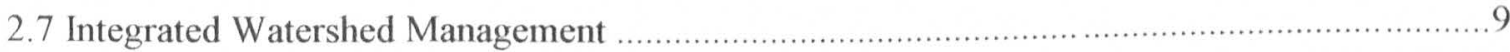

\section{Chapter 3}

Study Area

3.1 Bamyan Province

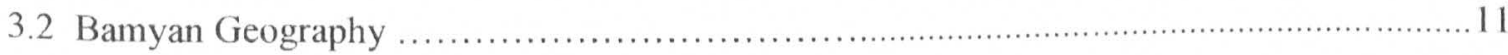

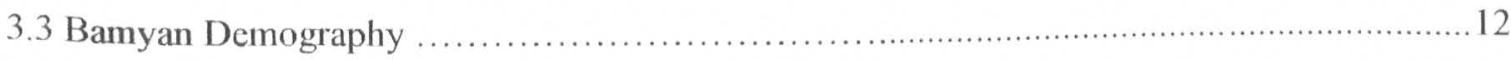

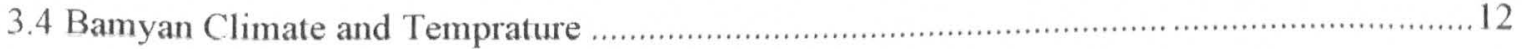




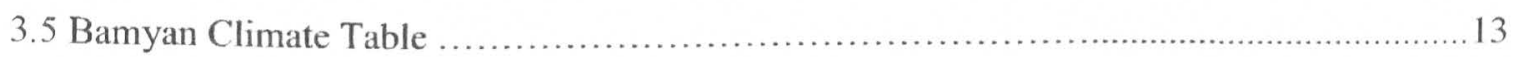

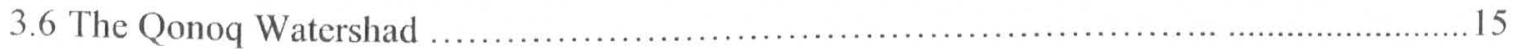

3.7 Types of soil and water conservation measures of qonoq watershed............................... 16

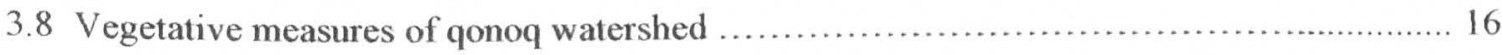

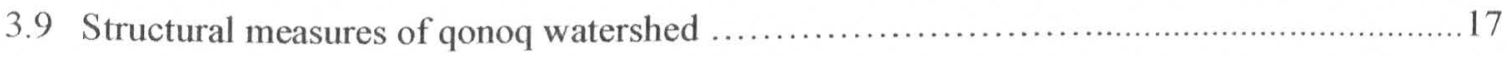

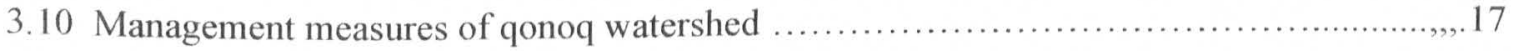

3.11 Strates for Sustainable Soil Conservation and Watershed Development..............., ,.. 18

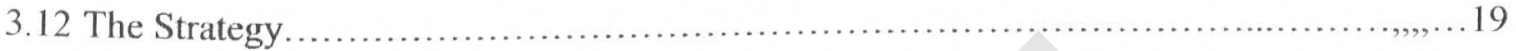

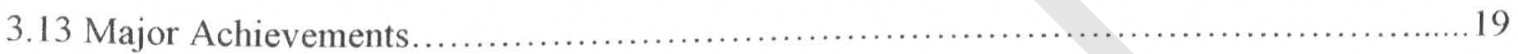

\section{Chapter 4}

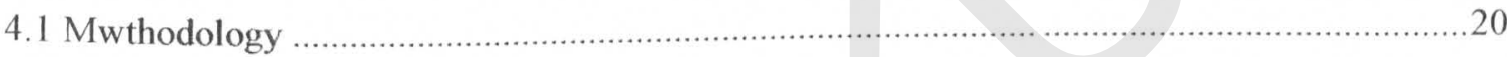

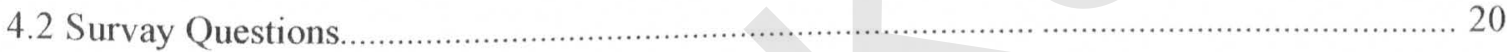

4.3 Sample Size Determination Using Krejcie and Morgan Table.....,,,,, ....................21

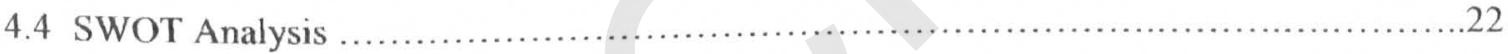

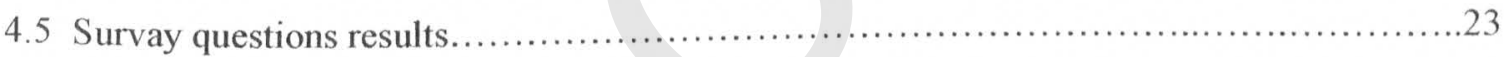

\section{Chapter 5}

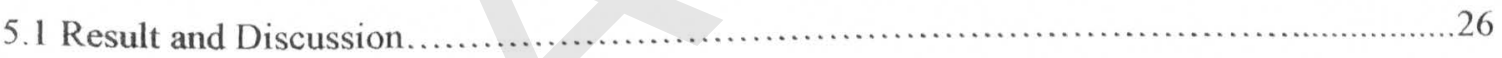

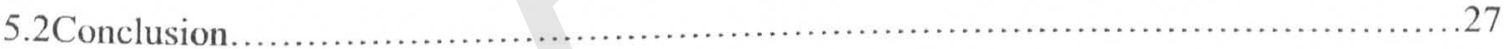

Recommenditions

Reference 


\section{LIST OF TABLE}

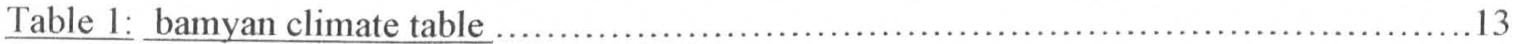

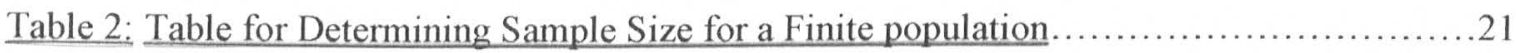

\section{LIST OF FIGURES}

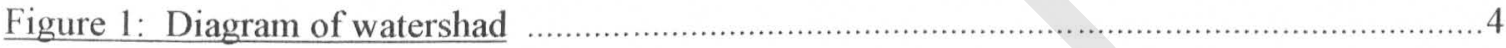

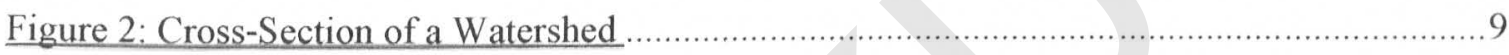

Figure 3: Bamyan Map

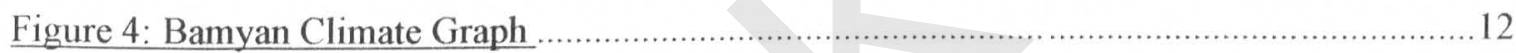

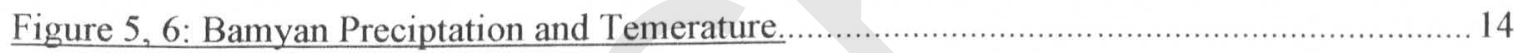

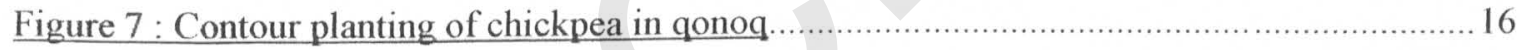

Figure 8: Brushwood structures using willow in waras district........................................... 17

Figure 9: Earthen V-shaped and other bunds in waras district ........................................... 17

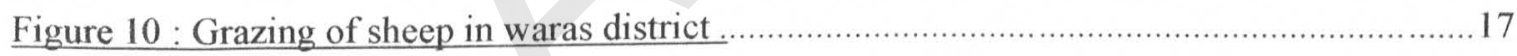

Figure 11 : Structural measures with vegetative measures in Waras district. ...........................18

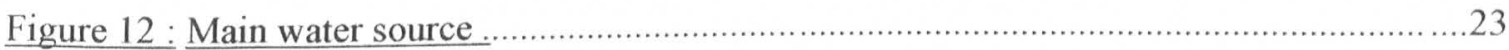

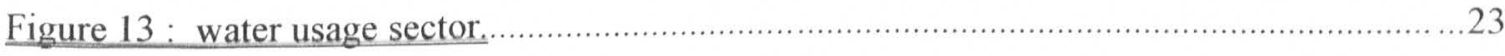

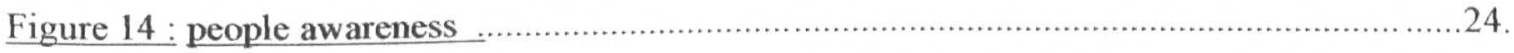

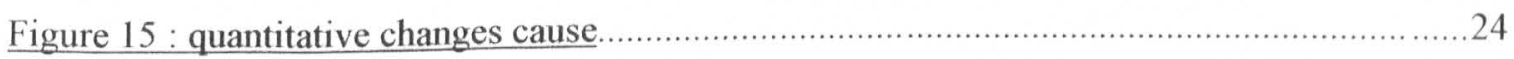

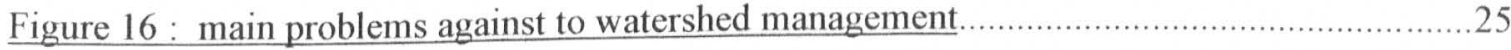




\section{CHAPTER 1}

\section{1 preface}

After six month of invistigation of integrated watershed management, it is timely to take stock of what has been learned and to draw out pointers that can help define future development paths.

This monograph has therefore been prepared as a Integrated Watershed Management, a case study of qonoq watershed in bamyan province. The watershed of Qonoq lies in the most southerly district of Bamyan province. With communities found ranging between 2,900 and 3,300 m, the region experiences prolonged winter conditions, has few cropping options, and relies on melt snow for most of its water requirements. The area is ethnically and religiously homogenous, with communities mostly belonging to the same ethnic and religious groups, but competition over diminishing resources and inter-familial rivalry have historically limited the possibilities of coordinated natural resource management at the community level.

the Aga Khan Foundation (AKF) started an integrated Micro Area. Development Programme which focused on integrated and broad ranging activities in specific watersheds in order to demonstrate pilot technologies and possible approaches to ensure impact.

The programme's initial phase targeted four communities in one watershed. The area or 'manteqa' was characterised by highly denuded rangelands, limited access to water resources, extensive soil degradation, and widespread conflict over land ownership. The extent of the conflict was such that those in the lower catchment villages were unable to pass through the centrally located bazaar to the upper catchment villages. As a result, AKF's intervention focused initially on social mobilisation: working closely with community members on resolving issues of conflict, group formation, the election of community representatives, and building the capacity of individuals and newly formed institutions at the community level.

Once representative institutions were in place, planning for the watershed at the household,community, and cluster levels commenced. A broad range of integrated activities including literacy, self-help group formation, child-to-child education, crop and horticulture improvement composting, and greenhouse projects commenced. However, the objective of this monograph is the soil and water conservation work involving community planned structures such as bunds, terraces, trenches and pits in the upper catchment zones at the watershed level that ultimately facilitated community members to recognise the importance of working together. By planning within a given space, highlighting the interrelatedness of ecological connections and the inherent linkages between upper and lower catchment areas that the communities that compose the Qonoq watershed united in order to manage their own natural resources. 
The monograph has drawn on two consecutive exercises survay questions and acadmic studies The first exercise reviewed the experience of $\mathrm{AK}$ foundation with disturbution of questionary. The second broadened the review to incorporate the contribution of recent academic and empirical studies to thinking about watershed management. The audience for the survay questions includes families, educational, farmers, and young generation.

The invistigation begins with research question, qbjectives, importance of research, and research hypothesis (Chapter 1).Definitions of watersheds and watershed management, a characterization of the problem of watershed degradation, and a short history of watershed management operations and policies include in (Chapter 2). The following three chapters discuss the findings from experience with implementing watershed management programs based both on the project review and on the literature. Chapter 3 discusses the findings on Bamyan province geography, demography, climate, temprature, and the Qonoq watershed all characterization. Chapter 4 looks at findings on survay question for watershed management, methodology and sample size determination by using Krejcie and morgan table. A brief final chapter (Chapter 5) summarizes the principal conclusions and recommendations of the report.

\subsection{RESEARCH QUESTION}

How according to the action plan should have effective conservation of soil and water resources for sustainable production with minimum non point resources pollutant losses?

\subsection{OBJECTIVES}

Watershed management implies an effective conservation of soil and water resources for sustainable production with minimum non point resources pollutant losses. It involves management of land surface and vegetation so as to conserve the soil and water for immediate and long term benefits to the farmers, community and society as a whole.

\subsection{IMPORTANCE OF RESEARCH}

A watershed is a natural hydro-geological unit ecologically linking people, the sun, soil, water, and biomass cover from which precipitation finds a common outlet. It exists regardless of political boundaries and necessarily incorporates interactions between upper and lower catchments.

Because it specifically acknowledges the natural physical space, watershed management is a uniquely appropriate approach for programme implementation, community planning, and technical interventions and monitoring.

The advantages from a community-managed and planned watershed in Afghanistan could include the following possibilities. 
- Improved water availability

- Improved water quality

- Reduced risks of natural disasters

- Higher yields

- Increased biomass cover

- Improved soil quality

- Increased income generation activities

- Improved habitats for flora and fauna and, therefore, improved biodiversity

\subsection{RESEARCH HYPOTHESIS}

Watersheds bear significant importance from ecological, aesthetic and socio-economic perspectives. These watersheds are home to millions of people, a substantial proportion of whom are indigenous ethnic minorities eking out their livelihoods by utilizing natural resources available there. As much as $65 \%$ of the rural population of Asia, and a much larger percentage of its poor, live in upland regions. In Bamyan, half of the population lives in the mountain areas and the overwhelming majority of them cannot meet subsistence levels. To what extent or how long the ecosystem-balancing and economic opportunity-generating roles of watersheds will continue depends on their status as reflected in the distribution, density and type of vegetation cover, and the pace of soil erosion and land productivity. Due to the lack of comprehensive macro-level studies, no conclusions can be drawn about the status of watersheds on a regional scale. However, findings of several micro-level studies indicate that watersheds are undergoing soil erosion, soil nutrient depletion and deforestation, though the extent of these problems varies from one area to another. 


\section{CHAPTER 2}

\subsection{INTRODUCTION}

A watershed is an area of land that drains all the streams and rainfall to a common outlet such as the outflow of a reservoir, mouth of a bay, or any point along a stream channel. The word watershed is sometimes used interchangeably with drainage basin or catchment. Ridges and hills that separate two watersheds are called the drainage divide. The watershed consists of surface water-lakes, streams, reservoirs, and wetlands--and all the underlying ground water. Larger watersheds contain many smaller watersheds. It all depends on the outflow point; all of the land that drains water to the outflow point is the watershed for that outflow location. Watersheds are important because the streamflow and the water quality of a river are affected by things, humaninduced or not, happening in the land area "above" the river-outflow point.

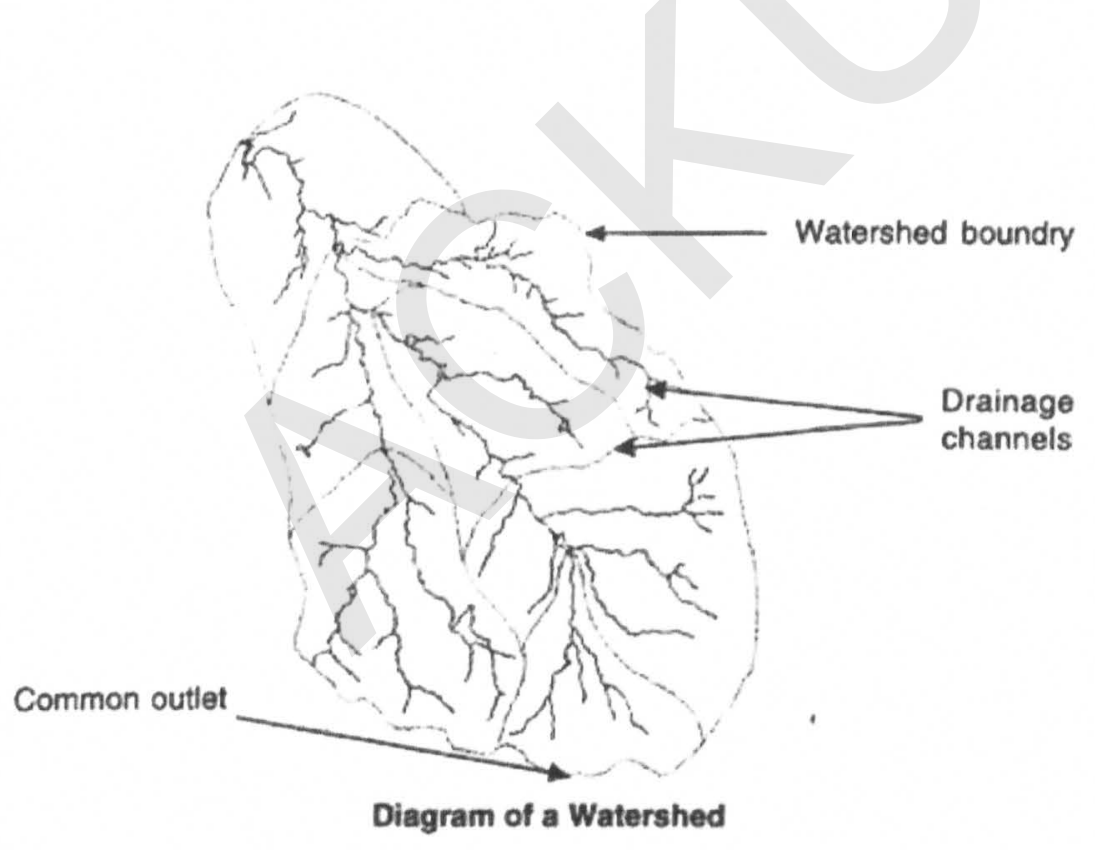

Figure 1.1:Diagram of watershad.(USGS 2018)

- Precipitation: The greatest factor controlling streamflow, by far, is the amount of precipitation that falls in the watershed as rain or snow. However, not all precipitation that falls in a watershed flows out, and a stream will often continue to flow where there is no direct runoff from recent precipitation. 
- Infiltration: When rain falls on dry ground, some of the water soaks in, or infiltrates the soil. Some water that infiltrates will remain in the shallow soil layer, where it will gradually move downhill, through the soil, and eventually enters the stream by seepage into the stream bank. Some of the water may infiltrate much deeper, recharging groundwater aquifers. Water may travel long distances or remain in storage for long periods before returning to the surface. The amount of water that will soak in over time depends on several characteristics of the watershed:

- Soil characteristics: In Georgia, clayey and rockey soils of the northern areas absorb less water at a slower rate than sandy soils, such as in Georgia's Coastal Plain. Soils absorbing less water results in more runoff overland into streams.

- Soil saturation: Like a wet sponge, soil already saturated from previous rainfall can't absorb much more ... thus more rainfall will become surface runoff.

- Land cover: Some land covers have a great impact on infiltration and rainfall runoff. Impervious surfaces, such as parking lots, roads, and developments, act as a "fast lane" for rainfall - right into storm drains that drain directly into streams. Flooding becomes more prevalent as the area of impervious surfaces increase.

- Slope of the land: Water falling on steeply-sloped land runs off more quickly than water falling on flat land.

- Evaporation: Water from rainfall returns to the atmosphere largely through evaporation. The amount of evaporation depends on temperature, solar radiation, wind, atmospheric pressure, and other factors.

- Transpiration: The root systems of plants absorb water from the surrounding soil in various amounts. Most of this water moves through the plant and escapes into the atmosphere through the leaves. Transpiration is controlled by the same factors as evaporation, and by the characteristics and density of the vegetation. Vegetation slows runoff and allows water to seep into the ground.

- Storage: Reservoirs store water and increase the amount of water that evaporates and infiltrates. The storage and release of water in reservoirs can have a significant effect on the streamflow patterns of the river below the dam.

- Water use by people: Uses of a stream might range from a few homeowners and businesses pumping small amounts of water to irrigate their lawns to large amounts of water withdrawals for irrigation, industries, mining, and to supply populations with drinking water. 


\subsection{Types of Watersheds}

Watershed types are based on the type of drain target the watershed has.

A drain target is the location where the water flow either stops or leaves the surface. Water that flows along an area or across a surface triangle eventually flows off the surface, or it reaches a point from which there is no downhill direction.

For each drain target in a surface, AutoCAD Civil 3D determines the region of the surface that drains to that target. This region is called the watershed for that drain target.

Each watershed that you delineate is categorized as one of the following types, based on drain target.

\section{Topics in this section}

\section{- Boundary Point}

If the downhill end of a channel edge is on the surface boundary, then water flowing through that channel continues off the surface. The boundary point is the lowest end of the channel.

\section{- Boundary Segment}

If an edge on the surface boundary belongs to a triangle that slopes down toward that edge, then water flows off the surface all along that edge. A boundary segment is a connected sequence of such edges.

\section{- Depression}

If a point is at a lower elevation than all its neighboring TIN points, then when water flows to it, it has no downhill place to go. Similarly, a connected set of points that are at the same elevation and all of whose neighbors are at a higher elevation, is a single drain target. A depression is any such set of points.

\section{- Flat Area}

A flat area watershed is a flat area, from which water could flow down to more than one drain target. It also includes the parts of the surface that drain to that flat area. A flat area is a connected set of triangles all of whose vertices have the same elevation. Flat areas abut parts of the surface that slopes downhill.

- Multi-Drain

One type of ambiguous watershed is called a multi-drain or split channel watershed.

\section{- Multi-Drain Notch}

A multi-drain notch watershed occurs where there is a a flat edge between two points on a surface. 


\subsection{Watershed management}

Watershed management is the study of the relevant characteristics of a watershed aimed at the sustainable distribution of its resources and the process of creating and implementing plans, programs, and projects to sustain and enhance watershed functions that affect the plant, animal, and human communities within the watershed boundary. Features of a watershed that agencies seek to manage include water supply, water quality, drainage, stormwater runoff, water rights, and the overall planning and utilization of watersheds. Landowners, land use agencies, stormwater management experts, environmental specialists, water use surveyors and communities all play an integral part in watershed management.

\subsection{The Evolution of National Policies in Watershed Management}

National policies on watershed management have tended to develop in a pragmatic and iterative fashion, with early setbacks over engineering-dominated approaches being succeeded by tests of community-based approaches and by technology packages targeting sustainable changes in land and water use practices that brought profit to stakeholders. In several countries, including Brazil, China, India, and Turkey, success in testing community-based approaches has led to adoption of broader policies for community-based watershed management. In other countries, including Morocco and Indonesia, doubts about program performance and cost have delayed the adoption of national policies.

\subsection{Watershed Management Approaches and Methodologies}

\section{The Scales of intervention in Watershed Management}

Watershed management programs generally adopt the micro-watershed level as the basic management unit, since this allows the integration of land, water, and infrastructure development and the inclusion of all stakeholders in a participatory process, for example, in northeastern Brazil where the approach allowed the needs and interests of local groups to be integrated. The microwatershed has proved a flexible and practical unit for project implementation and has reduced costs. However, the definition of a micro-watershed needs to be adapted to the social, administrative, and physical context. Best practice is that choice of scale should be driven by a participatory analysis of problems throughout the watershed, preferably within a broader watershed planning framework, as was done in the Loess II Project in China. 
Base on this, programs can be clear from the beginning about the proposed scale of interventions and the socioeconomic, environmental, and technical criteria for defining the micro-catchment and forselecting which micro-catchments to target.

The micro-watershed approach also raises some difficulties when it comes to scaling up. Working at the micro-watershed scale does not necessarily aggregate or capture upstream-downstream interactions. A patchwork of upstream interventions would only have a significant impact downstream if prioritized and planned within the larger watershed context and with understanding of the spatial and hydrological links between the perceived externalities and their causal factors (for example, land and water use). The lesson is that integration of watershed management activities beyond the micro-watershed requires higher level technical planning. In best-practice approaches, planning includes an institutional mechanism where stakeholders have a voice and are able to agree on measures from the micro-watershed scale upwards that can achieve both local and larger-scale objectives. The approach also needs to deal with institutional challenges of interagency collaboration and local-regional-level coordination.

\subsection{The Policy and Legal Framework of Watershed Management}

Watershed management works best when there is a supportive policy and legal framework, particularly (a) policies that facilitate decentralized and participatory development, (b) institutional arrangements that allow and encourage public agencies at all levels to work together, and (c) an approach to access to natural resources that reflects local legislation and tenure practices and problems. Land tenure and common pool resources are a particular challenge for watershed management, and there needs to be a clear understanding of the policy and legal framework and local practices and of how a project can work within this framework to promote investment. Lack of such an understanding in the Turkey Eastern Anatolia Project led to failure of the pasture improvement component. Operations can also help in the process of preparing for and implementing reforms. 


\subsection{Integrated Watershed Management}

IWM Our activities on the land impact the health and sustainability of natural resources and can threaten how much water we have available as well as how well we can adapt to the impacts of climate change. The best way to protect resources is on a watershed basis using an integrated watershed management approach. This approach allows us to address multiple issues and objectives and enables us to plan within a very complex and uncertain environment.

Integrated watershed management (IWM) is the process of managing human activities and natural resources on a watershed basis, taking into account social, economic and environmental issues, as well as local community interests and issues such as the impacts of growth and climate change.

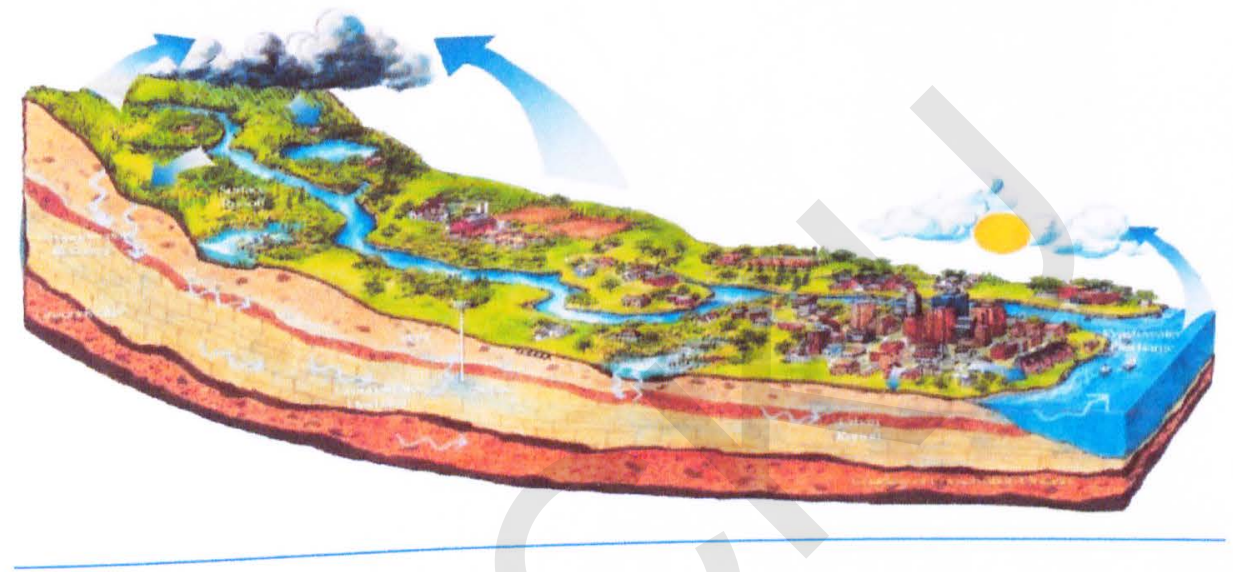

Figure 2 : Cross-Section of a Watershed. (Raphy Favre, Watershed Consultant,Watershed Atlas 2014) 


\section{CHAPTER 3}

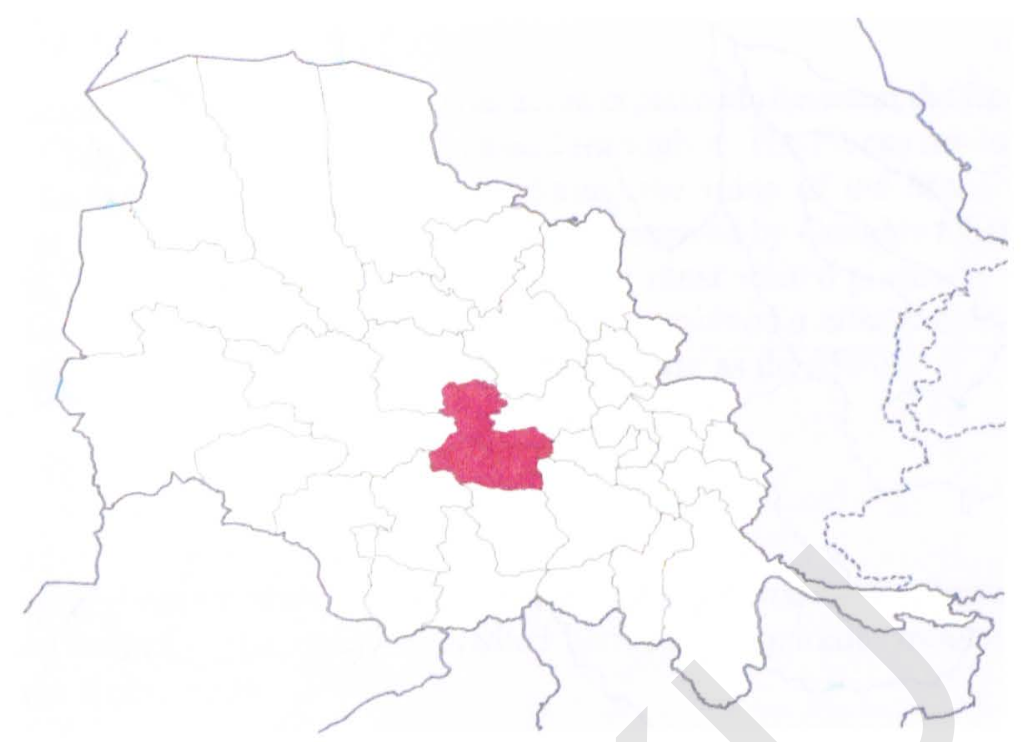

Figure 3: bmyan map(USGS 2018)

\subsection{Bamyan Province}

Bamiyan and Bamian, is the capital of Bamyan Province in central Afghanistan. With an altitude of about $2,550 \mathrm{~m}$ and a population of about 100,000, Bamyan is the largest town in the central Afghanistan region of Hazarajat, and lies approximately 240 kilometres north-west of Kabul, the national capital. Many statues of Buddha are carved into the sides of cliffs facing Bamyan city. In 2008, Bamyan was found to be the home of the world's oldest oil paintings. The city of Bamyan has a population of 100,000 (in 2014).It has four districts and a total land area of 3,539 hectares. The total number of dwellings in this city are 4,435 .

The Bamiyan valley marked the most westerly point of Buddhist expansion and was a crucial hub of trade for much of the second millennium CE. It was a place where East met West and its archaeology reveals a blend of Greek, Turkic, Persian, Chinese and Indian influence. The valley is one of Afghanistan's most touristic places. Bamyan City joined the UNESCO Creative Cities Network as a Crafts and Folk Art city in 2017. 


\subsection{Bamyan Geography}

Situated on the ancient Silk Route, the town was at the crossroads between the East and West when all trade between China and the Middle East passed through it. The Hunas made it their capital in the 5 th century. Because of the cliff of the Buddhas, the ruins of the Monk's caves, Shahr-e Gholghola ('City of Sighs', the ruins of an ancient city destroyed by Genghis Khan during the 1221 siege of Bamiyan), and its local scenery, it is one of the most visited places in Afghanistan. The Shahr-e Zuhak mound ten miles south of the valley is the site of a citadel that guarded the city, and the ruins of an acropolis could be found there as recently as the 1990s.

\section{Shahr-e Zuhak}

The town is the cultural center of the Hazara ethnic group of Afghanistan. Most of the population lives in downtown Bamyan. The valley is cradled between the parallel mountain ranges of the Hindu Kush and the Koh-i-Baba.

Bamyan is a small town with a bazaar at its center. It has no infrastructure of electricity, gas, or water supplies. According to Sister Cities International, Bamyan has established a sister city relationship with Gering, Nebraska, United States. It has an airport with a gravel runway.

Mountains cover ninety percent of the province, and the cold, long winter, lasting for six months, brings temperatures of three to twenty degrees Celsius below zero. Mainly Daizangi Hazara people live in the area. Transportation facilities are increasing, but sparse. Notably Bamyan is now connected by road to Kabul through Parwan province and through Maidan Wardak. The connection between Maidan Shar and Bamyan - $136 \mathrm{~km}$ long - makes it possible to reach Kabul in a 2-hour drive. The connection is almost completed missing just $15 \mathrm{~km}$ of paving

The main crops are wheat, barley, mushung, and baquli, grown in spring. When crops are damaged by unusually harsh weather, residents herd their livestock down to Ghazni and Maidan provinces to exchange for food.

The city and the province are served by Bamyan Airport. A new airport has been completed in 2015 with an asphalt runway. The project was funded by the Japanese Government and carried out by the United Nations Office for Project Services (UNOPS). 


\subsection{Bamyan Demography}

The population of this city is estimated to be 100,000 in 2016. Hazaras make up almost entire population of Bamyan.

\subsection{Bamiyan Climate $\&$ Temperature}

- Bamiyan, Afghanistan is at $34^{\circ} 49^{\prime} \mathrm{N}, 67^{\circ} 48^{\prime} \mathrm{E}, 2550 \mathrm{~m}(8366 \mathrm{ft})$.

- Bamiyan has a mid-latitude desert/ arid cool climate (Köppen-Geiger classification: BWk).

- According to the Holdridge life zones system of bioclimatic classification Bamiyan is situated in or near the boreal wet forest biome.

- The mean temperature is 6.9 degrees Celsius (44.4 degrees Fahrenheit). See the temperatures pagef or a monthly breakdown and the fixed scale graph.

- Average monthly temperatures vary by $24.8{ }^{\circ} \mathrm{C}\left(44.6^{\circ} \mathrm{F}\right)$. This indicates that the continentality type is continental, subtype subcontinental.

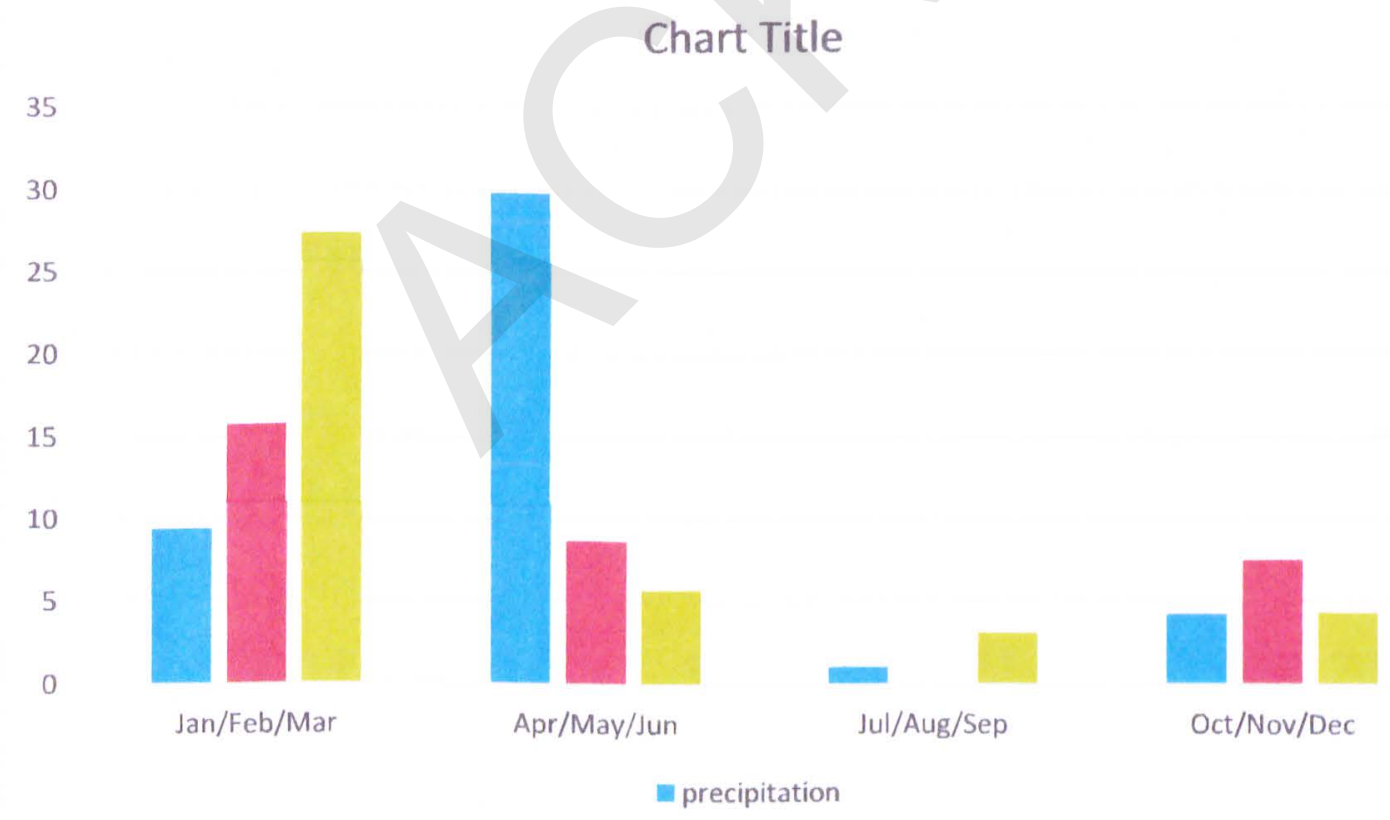

Figure 4; bamyan climate graph( water and energy departement of afghanistan) 
- Total annual Precipitation averages $133 \mathrm{~mm}$ (5.2 inches) which is equivalent to 133 Litres $/ \mathrm{m}^{2}$ (3.26 Gallons/ $\left.\mathrm{ft}^{2}\right)$.

- Were you to burrow down through the centre of the Earth from Bamiyan you would pop up nearest to the climate station at Isla De Pascua-Mataveri, Chile where you would find a Tropical wet climate.

\subsection{Bamiyan Climate Table}

mate

irable

Jan

Feb Mar

Apr May Jun Jul Aug Sep Oct Nov

Dec

Annual

erage

\begin{tabular}{|c|c|c|c|c|c|c|c|c|c|c|c|c|c|}
\hline $\begin{array}{l}\left.{ }^{\circ} \mathrm{F}\right) \\
\text { nperature }\end{array}$ & $1(34)$ & $2(36)$ & $8(46)$ & $\begin{array}{l}16 \\
(60)\end{array}$ & $20(68)$ & $24(75)$ & $26(79)$ & $\begin{array}{l}26 \\
(79)\end{array}$ & $\begin{array}{l}23 \\
(73)\end{array}$ & $\begin{array}{l}17 \\
(63)\end{array}$ & $\begin{array}{l}11 \\
(52)\end{array}$ & $5(41)$ & $15(59)$ \\
\hline $\begin{array}{l}\text { erage } \\
\text { nperature } \\
\left({ }^{\circ} \mathrm{F}\right)\end{array}$ & $-6(20)$ & $-5(23)$ & $1(35)$ & $9(47)$ & $12(54)$ & $16(61)$ & $18(65)$ & $\begin{array}{l}17 \\
(63)\end{array}$ & $\begin{array}{l}13 \\
(55)\end{array}$ & $\begin{array}{l}8 \\
(46)\end{array}$ & $2(35)$ & $\begin{array}{l}-3 \\
(27)\end{array}$ & $7(44)$ \\
\hline $\begin{array}{l}\text { erage } \\
\text { nperature } \\
\left({ }^{\circ} \mathrm{F}\right)\end{array}$ & $-12(10)$ & $\begin{array}{l}-11 \\
(13)\end{array}$ & $\begin{array}{l}-4 \\
(25)\end{array}$ & $3(37)$ & $6(42)$ & $9(47)$ & $10(50)$ & $\begin{array}{l}9 \\
(48)\end{array}$ & $\begin{array}{l}4 \\
(40)\end{array}$ & $\begin{array}{l}0 \\
(32)\end{array}$ & $-5(23)$ & $\begin{array}{l}-9 \\
(17)\end{array}$ & $0(32)$ \\
\hline $\begin{array}{l}\text { erage } \\
\text { cipitation } \\
\text { (in) }\end{array}$ & $8(0)$ & $16(1)$ & $27(1)$ & $30(1)$ & $26(1)$ & $6(0)$ & $1(0)$ & $0(0)$ & $3(0)$ & $4(0)$ & $8(0)$ & $4(0)$ & $133(5)$ \\
\hline $\begin{array}{l}\text { erage } \\
\text { ylight } \\
\text { urs/ Day }\end{array}$ & $10 \mathrm{~h} 05^{\prime}$ & $10 \mathrm{~h} 51^{\prime}$ & $\begin{array}{l}11 \mathrm{~h} \\
54^{\prime}\end{array}$ & $\begin{array}{l}13 \mathrm{~h} \\
01^{\prime}\end{array}$ & 13h 57' & $14 \mathrm{~h} 26^{\prime}$ & 14h 13' & $\begin{array}{l}13 \mathrm{~h} \\
25^{\prime}\end{array}$ & $\begin{array}{l}12 \mathrm{~h} \\
20^{\prime}\end{array}$ & $\begin{array}{l}11 \mathrm{~h} \\
13^{\prime}\end{array}$ & $\begin{array}{l}10 \mathrm{~h} \\
17^{\prime}\end{array}$ & $9 \mathrm{~h} 50^{\prime}$ & $12 \mathrm{~h} 00^{\prime}$ \\
\hline $\begin{array}{l}\text { altitude } \\
\text { olar noon } \\
\text { the } 21 \text { st } \\
\left({ }^{\circ}\right)\end{array}$ & 35.2 & 44.5 & 55.4 & 67.1 & 75.4 & 78.6 & 75.6 & 67.3 & 55.9 & 44.4 & 35.2 & 31.8 & 55.5 \\
\hline
\end{tabular}

Figure 1: bamyan climate table(water and energy department of afganistan) 


\section{Chart Title}

35
30
25
2
15
10
5
0
-5
-10
-15
-20

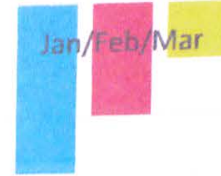

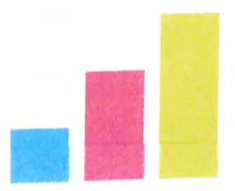

Apr/May/Jun

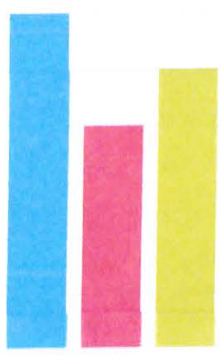

Jul/Aug/Sep

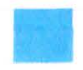

Oct/Nov/Dec

플 temperature

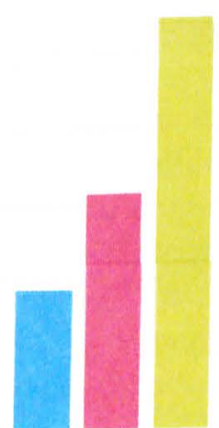

Jan/Feb/Mar

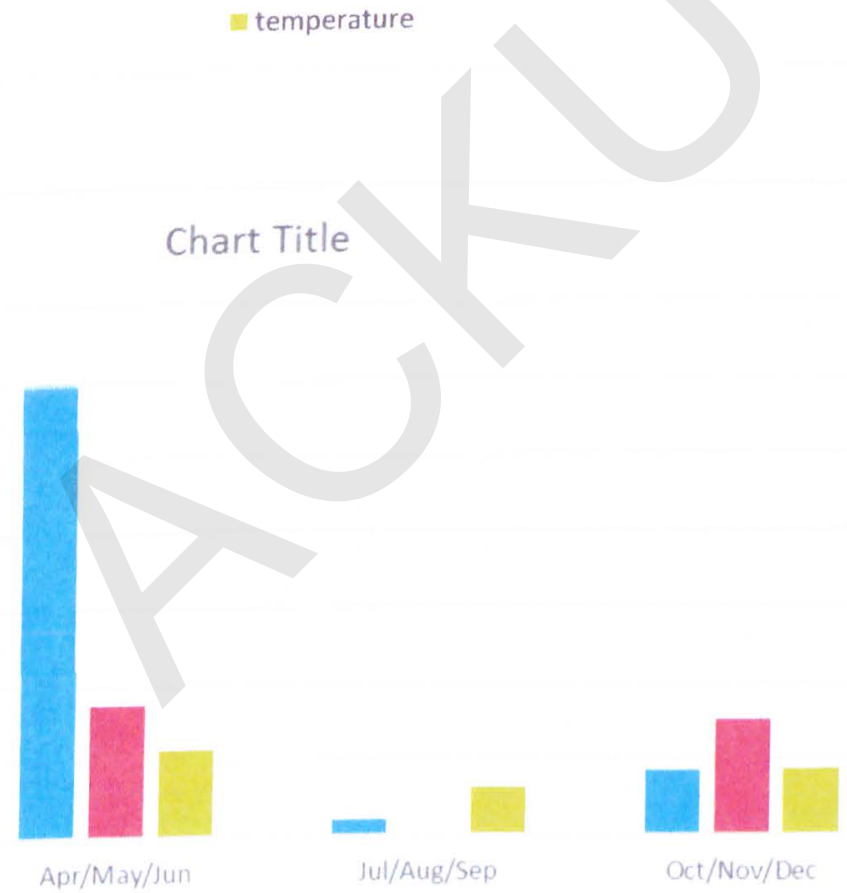

- precipitation

Figure 5,6 : bamyan preciptation and temerature ( water and energy department of Afghanistan) 


\subsection{The watershed of Qonoq}

The watershed of Qonoq lies in the most southerly district of Bamyan province. With communities found ranging between 2,900 and $3,300 \mathrm{~m}$, the region experiences prolonged winter conditions, has few cropping options, and relies on melt snow for most of its water requirements. The area is ethnically and religiously homogenous, with communities mostly belonging to the same ethnic and religious groups, but competition over diminishing resources and inter-familial rivalry have historically limited the possibilities of coordinated natural resource management at the community level.

In response to survey findings suggesting that Bamyan's southern provinces tended to be neglected by development programmes, the Aga Khan Foundation (AKF) started an integrated Micro Area. Development Programme which focused on integrated and broad ranging activities in specific watersheds in order to demonstrate pilot technologies and possible approaches to ensure impact.

The programme's initial phase targeted four communities in one watershed. The area or 'manteqa' was characterised by highly denuded rangelands, limited access to water resources, extensive soil degradation, and widespread conflict over land ownership. The extent of the conflict was such that those in the lower catchment villages were unable to pass through the centrally located bazaar to the upper catchment villages. As a result, AKF's intervention focused initially on social mobilisation: working closely with community members on resolving issues of conflict, group formation, the election of community representatives, and building the capacity of individuals and newly formed institutions at the community level.

Once representative institutions were in place, planning for the watershed at the household,community, and cluster levels commenced. A broad range of integrated activities including literacy, self-help group formation, child-to-child education, crop and horticulture improvement composting, and greenhouse projects commenced. However, it was the soil and water conservation work involving community planned structures such as bunds, terraces, trenches and pits in the upper catchment zones at the watershed level that ultimately facilitated community members to recognise the importance of working together. By planning within a given space, highlighting the interrelatedness of ecological connections and the inherent linkages between upper and lower catchment areas that the communities that compose the Qonoq watershed united in order to manage their own natural resources. 
Three years into the programme, the communities in Qonoq have created non-grazing conservation areas, rehabilitated significantly large tracts of upper rangelands through both social management, biological and mechanical structures, reseeded extensive upper catchment areas, and planned further watershed management work in their area. One-third of salaries earned by communities are voluntarily paid to the cluster level watershed management committee for the further management of the area. The Qonoq watershed has become a model for soil and water conservation in the high mountains of Afghanistan.

\subsection{Types of soil and water conservation measures in Qonoq watershed}

Agronomic measures such as mixed cropping, contour cultivation, mulching

- are usually associated with annual crops

- the measures can be repeated routinely each season, or in a rotational sequence

- are of short duration and do not lead to changes in slope profile.

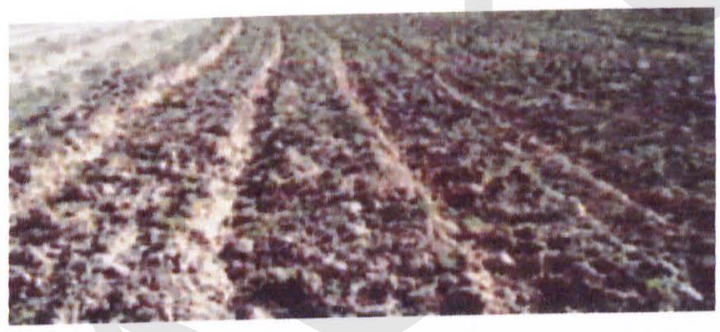

Figure 7: Contour planting of chickpea in qonoq

3.8 Vegetative measures such as grass strips, hedge barriers, windbreaks, brushwood in

\section{Qonoq watershed}

- involve the use of perennial grasses, shrubs or trees

- are of long duration

- often lead to a change in slope profile

- are often aligned along the contour or against the prevailing wind direction, and

- are often spaced according to slope 


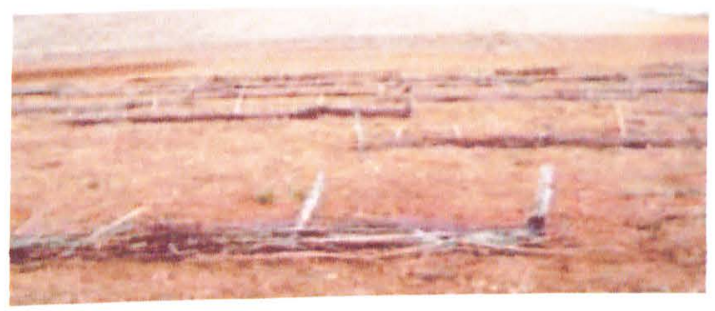

Figure 8: Brushwood structures using willow in waras district

3.9 Structural measures such as terraces, banks,bunds, palisades, drip irrigation in Qonoq watershed

- often lead to a change in slope profile

- are of long duration or permanent

- are carried out primarily to control runoff, wind velocity, and erosion, and to harvest rainwater

- are often aligned along the contour against prevailing wind direction

- are spaced according to slope

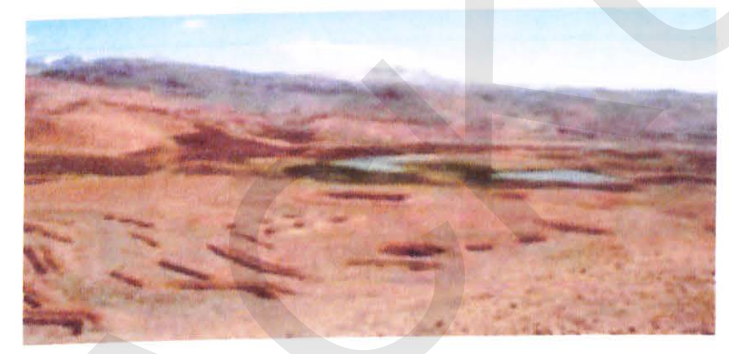

Figure 9: Earthen V-shaped and other bunds in waras district

3.10 Management measures such as land use change, area closure, rotational grazing in Qonoq watershed

- involve a fundamental change in land use

- involve no agronomic and structural measures

- often improve vegetative cover, and

- reduce the intensity of land use

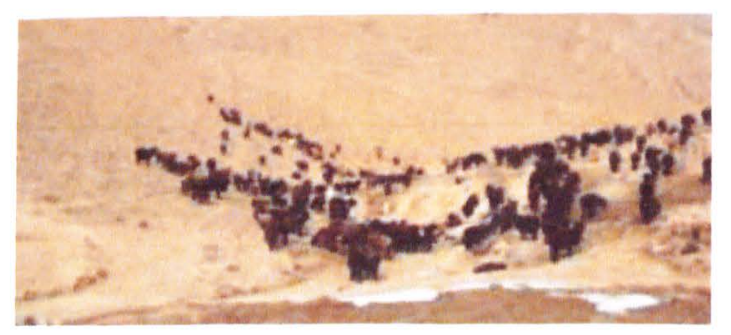

Figure 10: Grazing of sheep in waras district 
Combination of any of these measures in conditions where different measures are complimentary and produce more effective results.

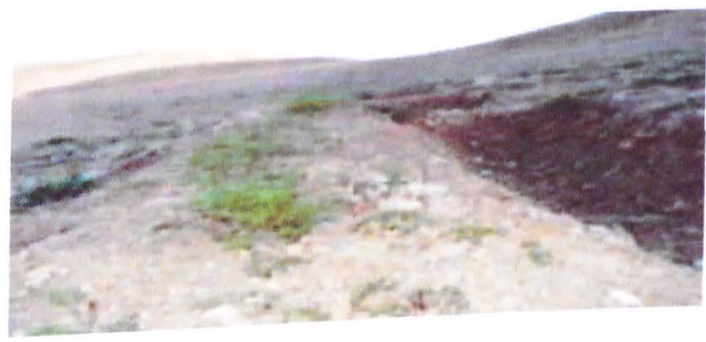

Figure 11: Structural measures (in this case, contour bunds) with vegetative measures in Waras district.

\subsection{Strates for Sustainable Soil Conservation and Watershed Development}

- Strengthen people's participation in watershed development of qonoq watershed. Make the beneficiary men and women active participants and not mere passive recipients of projects and interventions.

- Involve all possible stakeholders. Identify and involve them, consider their views, and implement their workable suggestions. This encourages participation and ownership. Stakeholders include people from the watershed communities such as landlords, small and marginal farmers, the landless; external institutions such as government and nongovernment organisations, research and financial institutions, and others.

- Focus on appropriate technologies for watersheds. Farmers' own innovations with low- cost technologies can also be valuable resources.

- Conduct action research for watershed technology and management to support programme work.

- Mobilise resources for watershed management. Apart from public funding, explore the possibility of funding watershed activities through community-based and private institutions. A much larger area of rural credit should flow into land development and land reclamation.

- Build capacities and develop human resources for watershed management. Provide training to the community of watershed users and bring them to exposure visits to successful watershed projects. Farmers learn best by observing success stories from other farmers

- Ensure project financial sustainability. Self-help groups organised as part of the project activities can play a role in sustaining the activities.

- Conduct monitoring evaluation and impact assessment. Realistic performance indicators to assess the impact of the programme should be developed with the help of professionals and in consultation with the communities. 


\subsection{The Strategy}

The following strategies were adopted for appropriate implementation and success of Qonoq watershad:

Aim for an increase in cropped areas were in the upper reaches, where the agriculture is risky due to poor soil and moisture conditions with appropriate watershed management.

Improving the water availability for drinking and irrigation through various interventions.

$\square$ Creating livelihood opportunities for small and marginal farmers through afforestation and fodder development interventions.

Providing opportunities for investment in the non-farm sector

Providing greater control over household level resources and decision-making power to women; reduce the drudgery (in fetching water, fuel and fodder) through drinking water improvements, afforestation and fodder development interventions.

Equal wages (or the parity in wages) for women.

Facilitating the emergence of leadership and management skill pools at the village Level.

\subsection{Major Achievements}

The programme has led to substantial improvements in environmental conditions, irrigation facilities and land-use patterns, which have led to an improvement in overall agricultural productivity. The direct wage employment opportunities provided through the integarated qonoq watershad mamagement have provided immense relief to the landless and small and marginal farmers. These opportunities have made a significant contribution to household income, addressed immediate concerns at the household level and checked daily movement to urban centres in search of work. 


\section{CHAPTER 4}

\subsection{METHODOLOGY}

This monograph investaget the Integarted Watershad Management. Using Descriptive, Causal comparative, and Experimental models, considaring on talking to other groupsor people and gathering their input by disterbution of questionary according to the population.

Bamyan province lies on the highlands of Afghanistan. The province covers an area of $17,414 \mathrm{~km}$ of mostly dry, mountainous terrain with a number of rivers, the largest being the Punjab. Nearly the whole province is mountainous or semi mountainous, while only $1.8 \%$ of the area is made up of flat land. The province is divided into 7 districts. The provincial capital is Bamyan centre which has a population of about 80,900 Inhabitants. Bamyan has a total population of 425,500 . There are 55,513 households in the province and households on average have 7 members. It also seek Strates for Sustainable Soil Conservation and Watershed Development of the integrated approche in Qonoq watershad management.

\subsection{Survay Question}

1. How to control or even reverse the process of forest and rangeland degradation?

2. How to reduce the rate of soil erosion in agricultural land to a minimum possible limit?

3. What should be done to improve the soil fertility, so as to increase crop yield on a sustainable basis?

4. How to enable watershed settlers to improve their quality of life without inflicting damage on natural resources?

5. What the main source of water you are using, do you have access to enough water for your daily life, how much water you may use per capita; do you have access to enough water for your livestock and irrigation?

6. How many families relying on a single deep well in this area?

7. What is water management, have you heard about this issue? What it can be according to you.

8. What are the main crops you are producing in this area, do you harvest once per year or twice?

9. What are the main problems or inappropriate way of using water, and who are the cause of this problem community and or government?

10. According to you how this lake or wetland is going to be effective in case of flood control, soil erosion and landscape view of the area?

11. What the government and NGOs can do to improve this wetland in considering water management?

12. What can the best practice for better management of this land according to your experience?

13. Do you see seasonal change in water lever in this watershad? 


\subsection{Sample Size Determination Using Krejcie and Morgan Table}

The ever increasing need for a representative statistical sample in empirical research has created the demand for an effective method of determining sample size. To address the existing gap, Krejcie \& Morgan (1970) came up with a table for determining sample size for a given population for easy reference.

\begin{tabular}{|c|c|c|c|c|c|}
\hline$N$ & $s$ & $N$ & $S$ & $N$ & $s$ \\
\hline 10 & 10 & 220 & 140 & 1200 & 291 \\
\hline 15 & 14 & 230 & 144 & 1300 & 297 \\
\hline 20 & 19 & 240 & 148 & 1400 & 302 \\
\hline 25 & 24 & 250 & 152 & 1500 & 306 \\
\hline 30 & 28 & 260 & 155 & 1600 & 310 \\
\hline 35 & 32 & 270 & 159 & 1700 & 313 \\
\hline 40 & 36 & 280 & 162 & 1900 & 317 \\
\hline 45 & 40 & 290 & 165 & 1900 & 320 \\
\hline 50 & 44 & 300 & 169 & 2000 & 322 \\
\hline 55 & 48 & 320 & 175 & 2200 & 327 \\
\hline 60 & 52 & 340 & 181 & 2400 & 331 \\
\hline 65 & 56 & 360 & 186 & 2600 & 335 \\
\hline 30 & 59 & 380 & 191 & 2800 & 338 \\
\hline 75 & 63 & 400 & 196 & 3000 & 341 \\
\hline 80 & 66 & 420 & 201 & 3500 & 346 \\
\hline 85 & 70 & 40 & 205 & 4000 & 351 \\
\hline 90 & 73 & 460 & 210 & 4200 & 354 \\
\hline 95 & 76 & 430 & 214 & 5000 & 357 \\
\hline 100 & 80 & 500 & 217 & 6000 & 361 \\
\hline 110 & 86 & 550 & 226 & 3000 & 364 \\
\hline 120 & 92 & 600 & 234 & 8000 & 367 \\
\hline 130 & 97 & 650 & 242 & 9000 & 368 \\
\hline 140 & 103 & 700 & 248 & 10000 & 370 \\
\hline 150 & 108 & 750 & 25.4 & 15000 & 375 \\
\hline 160 & 113 & 800 & 260 & 20000 & 377 \\
\hline 170 & 118 & 850 & 265 & 30000 & 379 \\
\hline 180 & 123 & 900 & 269 & 40000 & 380 \\
\hline 190 & 127 & 950 & 274 & 50000 & 381 \\
\hline 200 & 132 & 1000 & 278 & 75000 & 382 \\
\hline 210 & 136 & 1100 & 285 & 1000000 & 384 \\
\hline
\end{tabular}

Table 2: Table for Determining Sample Size for a Finite Population 
The Table is constructed using the following formula for determining sample

$S=X^{2} N P(1-P)+d^{2}(N-1)+X^{2} P(1-P)$

$\mathrm{S}=$ Required sample size

$\mathrm{X}^{2}=$ the table value of chi-square for 1 degree of freedom at the desired confidence level (3.841)

$\mathrm{N}=$ the population size

$\mathrm{P}=$ the population porportion ( assumed to be 50 since this would provide the maximm sample size)

$\mathrm{D}=$ the degree of accurancy expressed as a proportion $(05)$

\subsection{SWOT ANALYSIS}

The SWOT analysis was built in order to identify strengths and weaknesses in the qonoq watershad (as internal factors) and opportunities and treats (as external factors).

In particular, strengths and weaknesses, were identified based on the indicators evaluated in the basin and an overall brainstorming about the situation of water management issues for the watershad.

Opportunities and treats, were identified based on the watershad management analysis and the European and national legal framework (directives, regulations and Laws), cofinancing tools (European and national programmes), national strategic frameworks, developmental plans, water management plans... 


\subsection{The result of survay question:}

\section{MAIN WATER SOURCE}

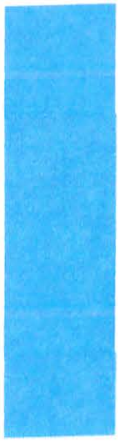

rivers

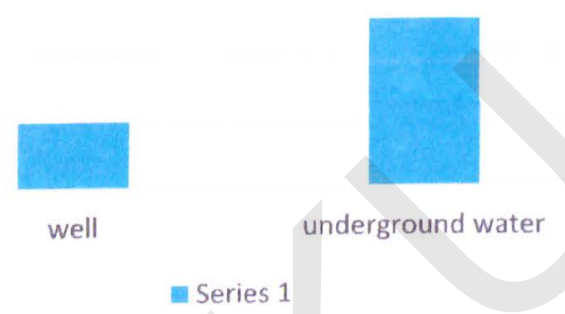

Figure 12: Main water source

WATER USAGE SECTOR

0

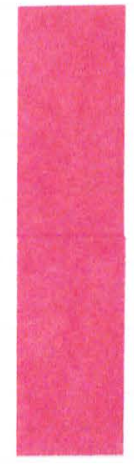

agriculture

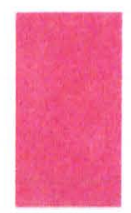

household

Series 2

Figure 13: water usage sector 


\section{PEOPLE AWARNESS}

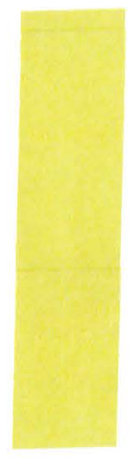

literated

Figure14: people awareness

\section{QUANTITATIVE CHANGES CAUSE}

100

90

80

70

60

50

40

30

20

10

0

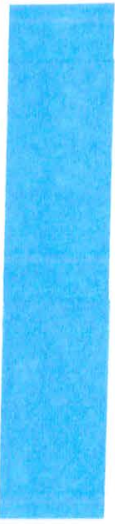

climate change

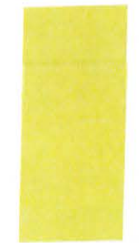

non literated

$$
\text { Series } 3
$$

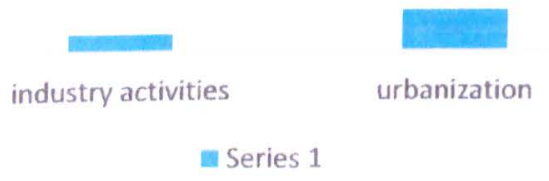

Figure 15: quantitative changes cause 


\section{PROBLEMS}

60

50

40

30

20

10

0

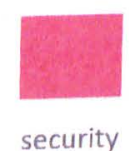

security

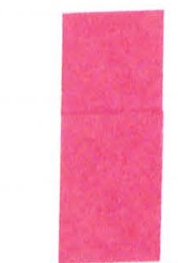

lack of specialists technical facilities

Series 2

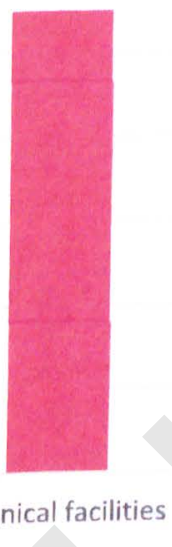

Figure 16: main problems against to watershed management 


\section{CHAPTER 5}

\subsection{RESULT AND DISCUSSION}

The increasing trend of involving people at every step of development builds an environment for better ownership, responsibility, and accountability. Decentralisation and governance increase the chances of implementing a community's needed activities on a sustained basis. The community begins to feel that development is their right rather than a mercy from development agencies. More effort should be made to recogniz the problem to impowerment of experts increase technical facilities quality and emphasise a decentralised implementation approach that meets local needs acoording to the national legal watershad farmeworks. In addition we focuse on survay questions to the prefect results.one survay question asked ( the people awareness, the learning opportunities available, and which would you be most likely to take advantage of for watershad management issues? The highest response by literateds was the printed fact sheets or brochures, followed by looking at demonstration or display, and website. The compaign will incorporate all three of these learning opportunities to help educate watershad residents.

Another servey question asked, what is your main water sources in this erea, the main source acoording to the qonoq climate was rivers. In addition they told me about water usage sectors, the agriclture sector is the most essiensial sector with high utalization of water in the region.

Most important survay question asked, in your opinion and your experience, what is the quantitative changes cause in watershad? The highest responses indicated the climate change effectes and other options in low level. Because of worse security in many provinces, one of my question survay, what is the main problems against to the watershad mangement and the highest responses shows the lack of technical facilities. 


\subsection{CONCLUSION}

The watershed management approaches implemented during the last 15 years have been generally successful in achieving goals of upland soil and water conservation and of intensification of natural resource use to increase the incomes of the upland population in asustainable way. Although there are significant variations in practice and performance, and although adaptation and flexibility are hallmarks of all good projects, some of the principalfactors of success can be listed. Characteristics of best-practice approaches have been the following:

Starting from the building block of the micro-watershed: Integrated Watershed management programs undertaken at the micro-watershed level clearly allow the needs and concerns of all stakeholders to be taken into account and an integrated package of land, water, and infrastructure to be developed that is responsive to needs.

Targeting actions to both livelihoods and natural resource conservation objectives: The new generation of projects has demonstrated that, although difficult, it is nonetheless oftenfeasible to target both improved livelihoods and conservation objectives, and a considerablebody of bestpractice has demonstrated ways to identify both stakeholder needs and appropriate technology.

Adopting participatory and decentralized approaches: Although effective participationimposes demanding requirements, participatory approaches and the use of community watershed management plans have often been effective in empowering communities and in gaining ownership of watershed management programs.

Demand-driven research and dissemination: Although many applied research programs have been lackluster, successful programs have been characterized by relative simplicity and demand drive, by participatory research and learning, and by careful up-front organization and incentives to ensure institutional cooperation.

Mainstreaming integrated watershed management within public institutions:Institutional arrangements for successful watershed management have been characterized by multidisciplinary and multiagency collaboration across ministries, by decentralization, and by institutional development at all levels. For sustainability, it has proved effective when watershed management programs and staff are located within permanent institutions. Other findings in the monograph suggest areas where changes may improve future watershed management approaches or where further analytic and empirical study is needed to develop good approaches. 


\subsection{RECOMMENDATION}

Watershed management demands harmonised integration of relevant aspects for the holistic development of communities. The issue here is what is the extent of integration: neither the integration of a few aspects which do not produce an impact, nor integration of many aspects, thus hindering implementation is good. For practical reasons, integration must be sought to the extent possible which ensures the programme gains momentum to function. This depends on social, political, and bureaucratic systems.So this is the issue to be decided based on local conditions.

Further attention to the poverty and watershed management interventions nexus is indicated, and a dialogue should be opened with other areas of practice that may be able to help develop better approaches, for example, rural and community-driven development, social fund programs, and decentralized land and water management programs, which have similar aims and target populations and which may have developed solutions that can be adapted to watershed management. Strengthening the Focus on Upstream and Downstream Interrelations in Watershed Management The report has identified a significant disconnect between objectives and what actually was produced in relation to downstream impacts. Downstream externalities played an important role in the justification for the projects to apply a watershed management approach, yet virtually no evidence has been produced of beneficial impacts, and there is some evidence of negative impacts. Little evidence exists that microlevel activities and institutions upstream actually contribute to improved conditions in the wider watershed. Watershed management programs have typically focused on on-site interventions, such as land improvement for the benefit of the local upland population. Similarly, stakeholder involvement and participation typically covered on-site needs of local farmers, and the spatial dimension was addressed through community-based planning of their territory. The institutional approach focused on the micro-watershed, with little or no cooperation across the watershed, or between upstream and downstream populations. Project success was also measured on-site, and the individual results (income increase, land area treated, yield increase) were typically summed up across the watershed area. There is little evidence from projects that the sum of all these demand-driven micro-level activities has had much impact on conditions downstream in the watershed, or even that the activities were optimal or cost-effective ways to improve conditions in the watershed.

At the level of overall programs, too, there has been little or no proof that upstreamactions have had a beneficial downstream effect. The targeting of downstream impacts at the level of project objectives was often based on assumptions that the overall improved upland management will have a beneficial outcome for the downstream location as well. In practice, M\&E systems were weak and did little to measure outcomes at the larger scale. A few projects measured sedimentation, but the impact of projects on downstream parameters received little attention in reporting. The impact of watershed management on water flow in particular received virtually no attention. Little direct attention has been paid to the water cycle in watershed management programs, even though one of the justifications of watershed management has been improvements in basin hydrology. Watershed management interventions globally have been targeted to manage land, and the subsequent impacts were assumed to provide benefits to the water cycle. However, little or no evidence exists that this is the case. In fact, watershed management programs appear in some cases to have actually produced negative impacts on downstream hydrology. 
Watershed management also has significant untapped potential to contribute to broader environmental objectives and to help in adaptation to climate change. Hitherto, watershed management programs have focused on direct soil and water impacts, but watershed management may address broader local, regional, and global environmental benefits. Programs may also contribute to adaptation to climate change.

Harnessing upstream activities to management objectives at the broader watershed level is evidently a major challenge. If integrated watershed management is to be justified by its beneficial impact on the downstream environment, institutional mechanisms are needed to integrate microwatershed programs into higher-level objectives at the overall watershed level, and to measure and monitor outcomes and impacts. The next phase of integrated watershed management programs will need to work toward an integrated institutional process with three complementary components:

A comprehensive process of watershed planning to set out the natural resource dynamics within the whole watershed and to identify critical environmental services to be protected. The level and complexity of this planning process will vary, but new institutional arrangements and a broader range of planning tools may be required that will be adapted to the particular context. These tools may range from environmental assessments to take account of broader environmental considerations and responses to climate change, through basinwide hydrological modeling and Integrated Water Resources Management approaches, to a comprehensive basin planning framework incorporating land and water resources together with other aspects of spatial planning. Stakeholder consultations and mechanisms for participatory diagnosis need to be integrated into the process.

A bottom-up institutional and investment process to negotiate between stakeholders, and to develop and measure the impact of a set of interventions that can fulfill both upstream objectives (at the local community level and also between upstream communities) and broader downstream objectives.

A much improved $M \& E$ methodology, incorporating research, measurement, and monitoring to provide the scientific and economic knowledge for managing and evaluating watershed management programs and for assessing and pricing costs and benefits. New modeling and satellite imagery tools can be of great value in this. Incentive structures for resource conservation need to be further developed to ensure that they are sustainable.

Sustainable watershed management requires an incentive structure that continues beyond the project period and that is supported by economic instruments that assign costs and benefits according to public and private good. The design of the incentive structure requires analysis of both local level incentives (what technologies, for example, could both achieve resource conservation objectives and justify stakeholder investment and effort) and the public good characteristic of conservation activities. The cases reviewed in the report show that much work remains to be done on this aspect, which deserves increased attention in the next round of watershed management programs. 
In conjunction with the further work recommended on identifying and valuing costs and benefits, research and analysis is needed to develop a methodology for designing equitable and sustainable incentive structures. In addition, further work is suggested on innovative instruments, such as payment for environmental services (PES). Here, research is needed to understand the relationship between land use and the generation of environmental services, to develop simple technical and economic tools for measuring costs and benefits and their distribution, and to define options for low-cost and practical institutional frameworks for PES. A framework is needed in watershed management initiatives for assessing and dealing with the policy, institutional, and program aspects of land tenure and common pool resources. Although land tenure and common pool resources have long been identified as critical in developing a sustainable incentive and institutional framework for watershed management, remarkably little systematic attention has been paid to handling the issues. Further research would help identify common issues and useful practices. The next round of Integrated watershed management projects should assess land tenure and common pool resource issues systematically in the initial diagnostic phase and develop a framework for dealing with them at the policy, institutional, and program levels. 


\subsection{REFERENCE}

1. Government of Afghanistan, MIWRE, "Classification and Numbering of Hydrological Stations", Kabul, 1976.

2. 54 Louis Dupree, "Afghanistan", Princeton Uni, 1973.

3. 55 Jidikov, A.P., "Hydrology", volume III, in FAO, "Report on Survey of Land and Water Resources. Afghanistan”,

4. 56 Klemm, W., Ibid., 1996.

5. 57 GEOCART, "National Atlas of the Democratic Republic of Afghanistan", Warsaw, 1984.

6. $58 \mathrm{UNEP} / \mathrm{FAO}$ and OSU, Ibid., 2002.

6. 58 UNEP/FAO UNEP/FAO and OSU. Ibid., 2002.
8. Oweyegha-Afunaduula, F.C., I. Afunaduula and M. Balunywa (2003). NGO-sing the Nile
8. 2003 Basin Initiative: a myth or reality? Paper at 3rd Wortedge, Chapter 4 ISBN 978-0415589826

9. Evans J: Environmental governance (2012), Rou (2002); Watershed Partnerships and the

10. Mark L, Mark S, John T and Institutions American Journal of Political Science, Emergence of Collective Action

11. Dhakal, K. P., \& Chevalier, L. R. (2016). Urban Stormwater Governance: The Need for a Paradigm Shift. Environmental management, 57(5), 1112-1124. Available at: http://rdcu.be/mRTi or at: https://doi.org/10.1007/s00267-016-0667-5

12. Ewalt, J. G. 2001. Theories of Governance antere Presented at the Annual Conference Understanding Welfare Policy for Public Administration. Also available at: of the American Society for $/$ public/documents/aspa/unpan000563.pdf.

http://unpan 1.un.org/intradoc/groups/pub_icte Partnerships for Storm Risk Management

13. Emma T and Lisa-Ann H (2010); Public-Privarch Institute, The University of Leeds. Also
in the Cayman in the Cayman Islands; Sustain. available at: http://www.see.leeds.ac.uk/research/sri/work 5 . Milward H and Provan K (2000). "How Networks Are Governed." In Heinrich C and
Lynn L eds. Governance and Performance: Models, Methods and Results, Page 243. Washington, DC: Georgetown University Press.

15. 8. Transboundary River Basin Management Regimes: the Rhine basin case study, Newater, pp 1-37. Also available at: http://www.tudelft.nl/live/binaries/9229ebc0-66d0-47ca-9d25$5 \mathrm{ab} 2184 \mathrm{c} 85 \mathrm{f} 4 / \mathrm{doc} / \mathrm{D} 131$ Rhine_Final.pdf

16. "Nile Basin Initiative".

17. 7. Prabhakar K, Lavanya K, and Papa Rao A (2010); NGOs and Farmers Participation in Watershed Development Programme in Prakasam District, Asia-Pacific Journal of Social Science, Volume II (1) Pages173-182. Also available at: http://www.socialsciencesejournal.org/3.9.\%20Prabhakar.pdf.

18. Mason, Karl; Duggan, Jim; Howley, Enda (2018). "A Meta Optimisation Analysis of Particle Swarm Optimisation Velocity Update Equations for Watershed Management Learning". Applied Soft Computing. 62: 148-161. doi:10.1016 j.asoc.2017.10.018

19. . FAO (2006) The new generation of watershed management programmes and projects. A resource book for 
20. practitioners and local decision-makers based on the findings and recommendations of an FAO review.

21. FAO Forestry Paper 150. Rome: Italy

22. Honore, Guy (ed) (2002) Principles and practices of integrated watershed management in India. New

23. Delhi: Indo-German Bilateral Project on Watershed Management

24. Sang-Arun, J; Mihara, M; Yamaji, E; Sombatpanit, S (2007) 'Monitoring and evaluation of soil conservation

25. and watershed development projects: An approach to sustainable development.' In de Graff, J;

26. Cameron, S; Sombatpanit, C; Piero Woodhill, J (eds.) Monitoring and evaluation of soil conservation

27. and watershed development projects. New Hampshire (USA): Science Publishers

28. Sthapit, KM (2000) Participatory approach of NARMSAP. Paper presented at the workshop on 'Integrated

29. Conservation and Development: Lessons Learned and Challenges for the Future' organised by the

30. Ministry of Foreign Affairs, Copenhagen, Denmark, on I September 2000 in Copenhagen, Denmark

31. Tideman, EM (1996) Watershed management: Guidelines for Indian conditions. New Delhi: Omega

32. WOCAT (2003) A framework for documentation and evaluation of soil and water conservation:

33. technologies. Revised WOCAT questionnaire February 2003, http:/www.wocat.org

34. Sharif, $S$ (1997) Irrigation engineers. Kabul: FAO

35. FAO/UNEP \& OSU, "The Atlas of International Freshwater Agreements", 2002. http:/www.transboundarywaters.orst.edu publications/atlas.

36. The definition is from A. T. Wolf, "Thematic Maps: Visualizing Spatial Variability and Shared Benefits", Oregon

37. State University, in FAO/UNEP \& OSU, "The Atlas of International Freshwater Agreements", 2002.

38. http: www.transboundarywaters.orst.edu publications/atlas/. The history of international water treaties dates as far

39. back as 2500 B.C., when the two Sumerian city-states of Lagash and Umma crafted an agreement ending a water

40. Giordano and A. T. Wolf, "The World's International Freshwater Agreements. Historical

41. Developments and Future Opportunities", Oregon State University, in FAO/UNEP, "The Atlas of International

42. Freshwater Agreements",

2003 , http: www.transboundarywaters.orst.edu publications/atlas/.

43. Krejcie, R.V., \& Morgan, D.W., (1970). Determining Sample Size for Research Activities. Educational and Psychological Measurement.

44. Small-Sample Techniques (1960). The NEA Research Bulletin, Vol. 38.

45. Based on preliminary work on social group definition in Afghanistan made by the author. See Favre, Raphy, "Interface between State and Society. An Approach for Afghanistan", 30 October 2003. 


\section{Kabul University}

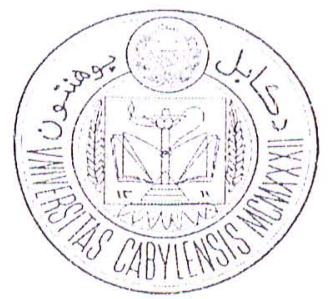

\section{يو هن ئحى محيط زيست}

هديريت عمومى تلدريسنى زيتى

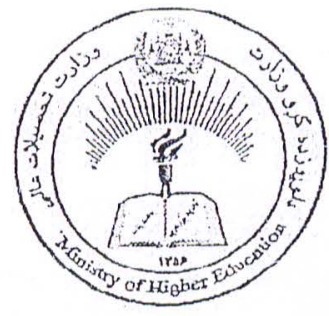

\section{تصديق ارزيابيى مونوكز افـ}

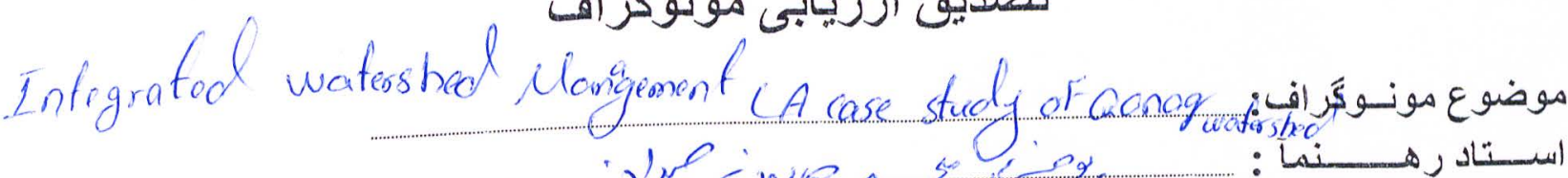
i) سمستر: نام بدر : رشام وتخلص : نحصيلي: شهرت تلدوين كننده مونوكُر اف :

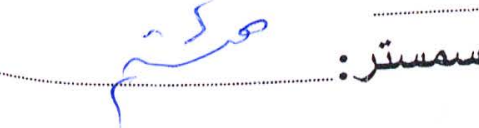
1 rav سال:...

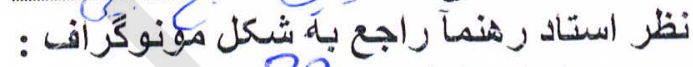

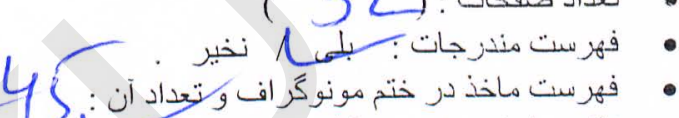

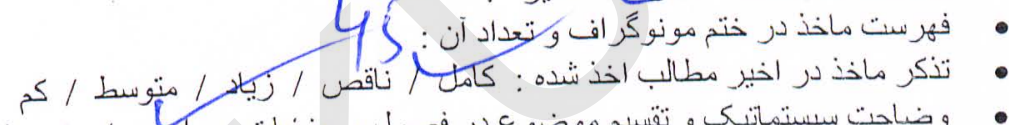

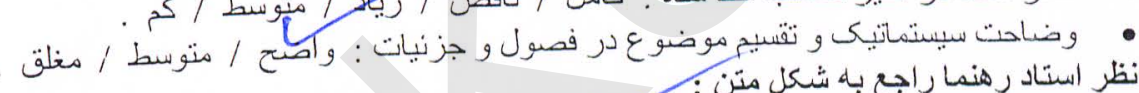

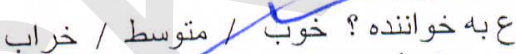

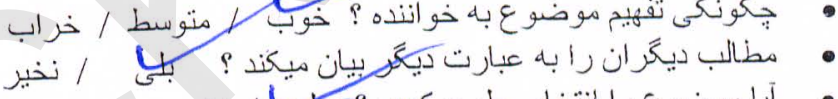
•

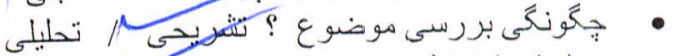

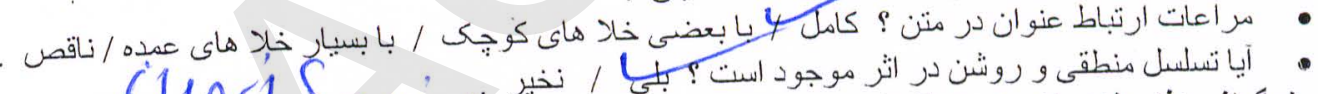

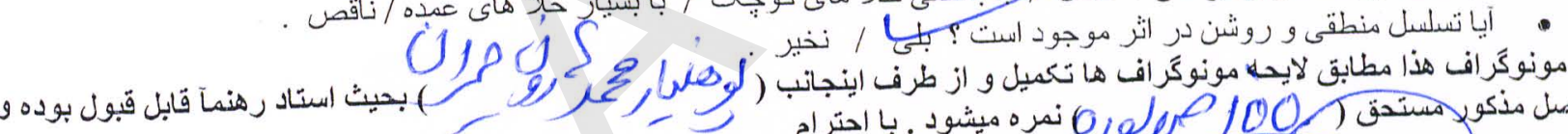

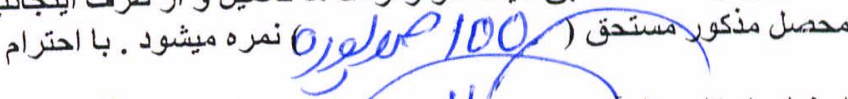
تاريخ/21397 / | | |

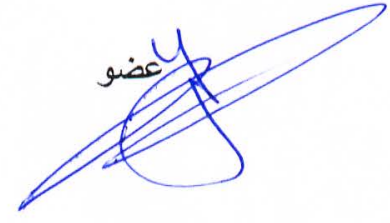

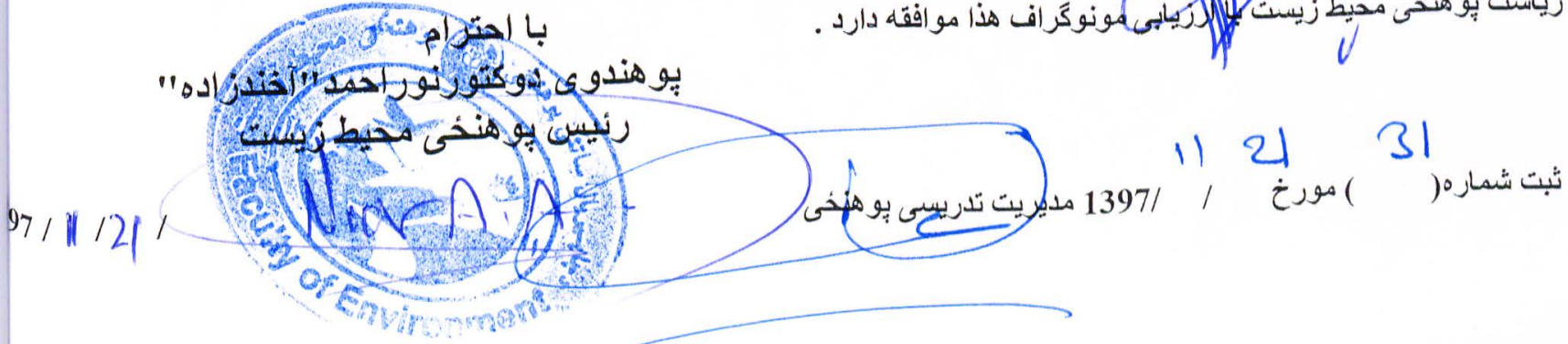

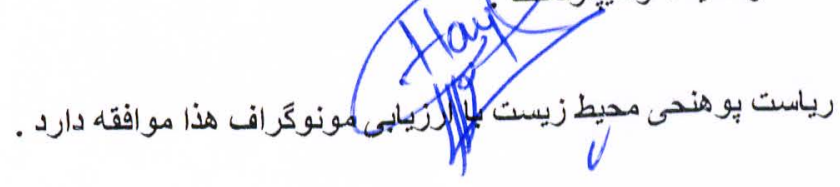

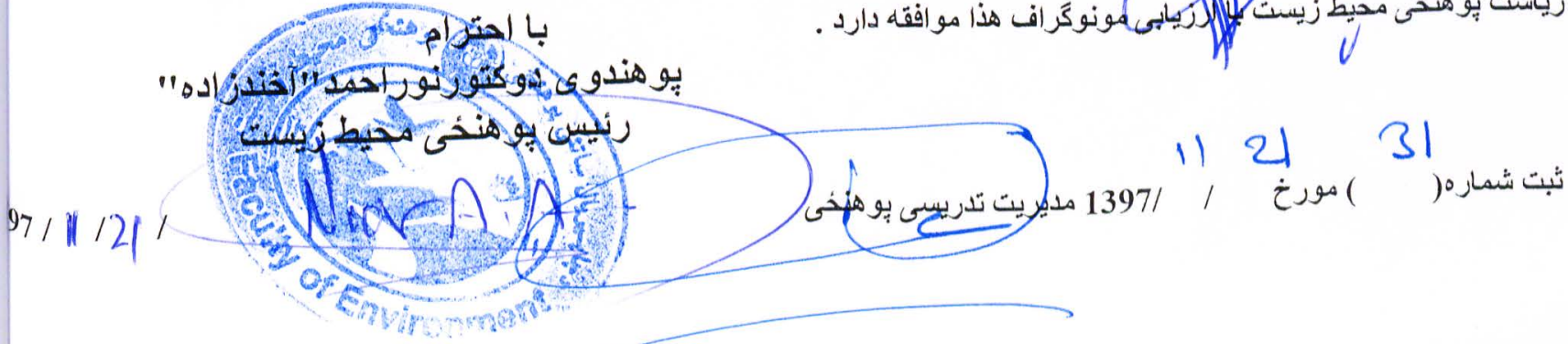
عضو

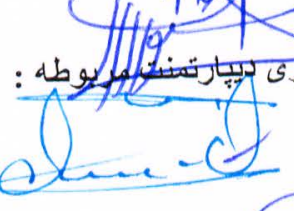
أمضاث استاد رهنما: 